\title{
Development of a Model to Estimate the Annual Available Amount of Forest Biomass Resources under Profitable Forest Management - Case Study of Nasushiobara City and Kanuma Area in Tochigi prefecture, Japan
}

Aruga, K.*, Murakami, A.*, Yamaguchi, R.. , Nakahata, C.*, Saito, M.*, \& Tasaka, T.*

Keywords: forest biomass resources, profitable forest management, economic balance, annual available amount, annual demand

Abstract: The purpose of this study was to develop a model to estimate the annual available amount of forest biomass resources under profitable forest management in the Nasushiobara city and Kanuma area of Tochigi prefecture, Japan. Economic balances regarding 60-year rotation were estimated based on two types of timber-harvesting systems (conventional operation system conducted by chainsaw and mini-forwarder, and mechanized operation system introducing processor and forwarder), and three types of forest biomass harvesting systems (normal extraction, landing sale, and no biomass extraction) in each subcompartment. The most economical timber and forest biomass harvesting system for each subcompartment was applied. As a result, the number of profitable, nonprofitable, and roadless subcompartments were 1,$801 ; 1,625$; and 2,330 of the total 5,756 subcompartments in Nasushiobara city whereas they were 8,$940 ; 3,014$; and 20,897 of the total 32,851 subcompartments in the Kanuma area. Then, the annual available amount of forest biomass resources was

Received July 22, 2012; Accepted October 25, 2012

* Utsunomiya University, Japan 
estimated as the annual supply potential of profitable subcompartments. The annual available amount of the forest biomass resources was $7,805 \mathrm{~m}^{3} /$ year and $50,313 \mathrm{~m}^{3} /$ year in Nasushiobara city and Kanuma area, respectively. This available amount meets the annual demand of $6,000 \mathrm{~m}^{3} /$ year of a $500 \mathrm{~kW}$ woody biomass power generation plant planned in Nasushiobara city, and the annual demand of $12,000 \mathrm{~m}^{3} /$ year of a chip production factory in the Kanuma area.

\section{Introduction}

In Tochigi prefecture, for the operation of facilities such as biomass power plants, chip production factories, and pellet plants, woody biomass is required. These resources mainly receive sawmill residue and construction waste wood. However, there are concerns regarding the adequacy of supplies of these materials because the number of entrepreneurs, who have set up biomass power plants, to countermeasure climate change has increased. Furthermore, feed-in tariffs (FIT) were introduced in Japan in July 1, 2012. In FIT, the purchase price of electricity generated with unused materials such as logging residue was $32 \mathrm{yen} / \mathrm{kWh}$ without tax, for materials such as sawmill residue it was 24 yen $/ \mathrm{kWh}$ without tax, and for recycled materials such as construction waste wood was $13 \mathrm{yen} / \mathrm{kWh}$ without tax (Agency for Natural Resources and Energy, 2012). Power generation with unused materials was given incentives to promote the use of logging residue.

In addition, the Tochigi prefecture area is 640,785 ha, out of which approximately $54.5 \%$ is covered by forests (Tochigi Prefectural Government, 2009). About half of these forests are manmade (44.9\%), and their volume is $42,255,000 \mathrm{~m}^{3}(62.4 \%)$. Because of delays in thinning operations, which was a serious problem for these manmade forests in Japan, the Tochigi Prefectural Government introduced a new taxTochigi no genkina moridukuri kenmin zei-to make forests healthy, along with subsidies for thinning operations, in April 2008 (Tochigi Prefectural Government, 2010a). As a result, thinning operations were 
conducted on 2,663 ha in 2009, but almost all thinning operations were precommercial. Therefore, a large amount of thinned woods was left in the forests.

Numerous studies have been conducted to examine the availability of woody biomass resources. Iuchi (2004) and Kamimura et al. (2009) developed techniques for estimating the supply potential of woody biomass, including logging residues, sawmill residues, and construction waste woods, in terms of regional energy in units of cities and towns. In addition to supply potentials, Yoshioka et al. (2005) and Kinoshita et al. (2009) devised techniques for estimating the regional harvesting volumes and costs of logging residues in units of sub-compartments corresponding to conventional forest management units in Japan, whereas Yagi et al. (2007) and Yamamoto et al. (2010) developed techniques that expressed them in units of kilometer-scale meshes or cities and towns. Furthermore, Aruga et al. (2006a) established a technique to estimate regional harvesting volumes and costs of both timber and logging residues in units of sub-compartments. Moreover, Aruga et al. (2006b) developed a technique for estimating forest biomass resource allocation to multiple regional plants in units of sub-compartments, whereas Ranta (2005) and Möller et al. (2007) devised a technique for expressing it at a national level.

In addition to these methods for the estimation of volumes and costs, Yamaguchi et al. (2010) developed a technique for estimating the available amount of logging residues in consideration of the economic balances estimated from regional revenues and costs of both timber and logging residues in units of sub-compartments, whereas Kinoshita et al. (2010) established a technique to express them in units of cities and towns. However, these studies have not considered regeneration expenses, which are important for conducting forest management, especially in plantation forests such as Japanese cedar and Japanese cypress 
in Japan. In contrast, Murakami et al. (2011) developed a method to extract production forests based on economic balances while considering the regeneration expenses. The study defined production forests as forests where expected revenue from clear-cutting surpassed costs such as harvesting and regeneration expenses. The revenue and costs were estimated based on forest registration and GIS data. However, that study considered thinning operations as costs in the regeneration expenses and did not consider any revenue from thinning operations because of the current situation in Japan, where nearly all thinning operations are precommercial and a large amount of thinned woods is left in the forests.

In this study, we developed a method to extract production forests considering forest biomass harvesting, which uses materials such as logging residue. We also defined production forests as forests where the expected revenues surpass all costs from planting to final harvesting. We have considered costs as well as revenue from thinning operations unlike Murakami et al. (2011). Then, we developed a model to estimate the annual available amount of forest biomass resources from profitable subcompartments considering the regeneration expenses. Finally, we examined the effects of regeneration costs, forest road network, and extending forestry operation sites on the annual available amount of forest biomass resources.

\section{Study Sites and Data}

The study sites were the Nasushiobara city and Kanuma area in Tochigi prefecture, Japan (Figure 1). The gross area of Nasushiobara city is 59,280 ha; the forest area is 38,689 ha and covers $65 \%$ of the gross area. The area of national forests is 24,981 ha, and the area of private and local government forests is 13,708 ha. We studied major plantation species such as Japanese cedar and Japanese cypress owned 
by privates and local governments. The area and number of subcompartments of Japanese cedar and Japanese cypress owned by privates and by local governments were 2,850 ha and 7,340, and 1,103 ha and 2,521, respectively (Figure 2). These forests are mainly 45-55 years old. The northern parts of Nasushiobara city are mountainous. However, these parts are almost the national forests, and the private and local government forests are located on relatively gentle slopes. The average slope angle is rather low, $10^{\circ}$, and the road network density is rather high, $27 \mathrm{~m} / \mathrm{ha}$. An agrarian organization in Nasunogahara area in Tochigi Prefecture is willing to conduct thinning operations and extract thinned woods for woody biomass power generation (Figure 2) cooperated with a Forest Owners' Cooperative in Nasushiobara city to maintain forests for soil and water conservation and to nurture river sources.

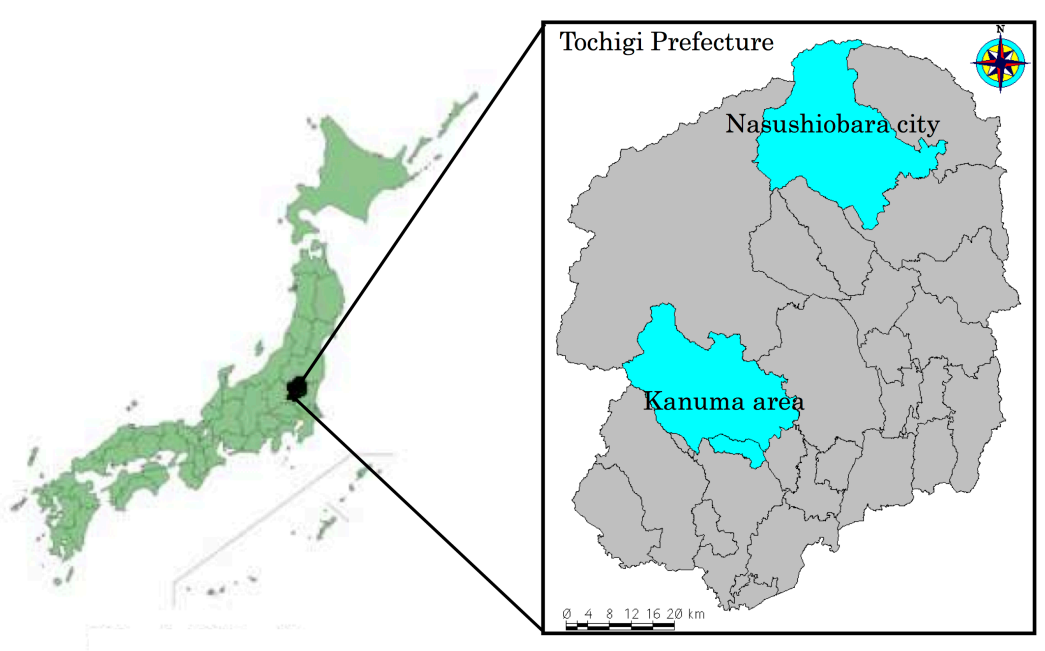

Figure 1. Study site.
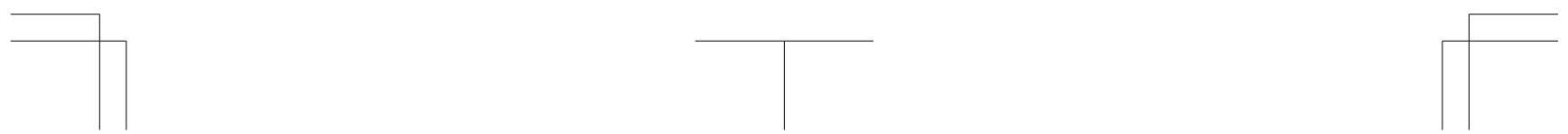
The Kanuma area consists of Kanuma city and Nishikata town (Figure 1). The gross area is 52,200 ha and forest area is 35,593 ha ( $68 \%$ of the gross area). The area of national forests is only 1,642 ha, and the area of private and local government forests is 33,951 ha. The area and number of subcompartments of Japanese cedar and Japanese cypress privately owned and that owned by local governments are 17,341 ha and 30,104, and 9,950 ha and 19,957, respectively (Figure 2). These forests are also $45-55$ years old. The western parts of Kanuma area are mountainous. The average slope angle is rather high, $22^{\circ}$, and the road network density is rather low, $18 \mathrm{~m} / \mathrm{ha}$. The site index, which ranks the order of the productivity of the stands, was high relative to Nasushiobara city, and that made the Kanuma area one of the prominent forestry areas in Tochigi Prefecture. However, the forestry industry has been in decline for a long time. Therefore, bioenergy is attracting attention because the energy use of forest biomass resources is expected to revitalize the forestry industry as well as the maintenance of the appropriate ecological, economic, and social functions of manmade forests. A chip production factory to supply chips to a woody biomass power generation plant is located in Kanuma area.

In this study, we used forest registration data (stand ages, tree species, and site indexes) and GIS data (information on roads and subcompartment layers) from the Tochigi Prefectural Government, and the $50 \mathrm{~m}$ grid digital elevation model (DEM) of the Geographical Survey Institute. The area and number of subcompartments of Japanese cedar and Japanese cypress privately owned and that owned by the local government of Nasushiobara city were 2,761 ha and 4,456, and 918 ha and 1,300 on the $50 \mathrm{~m}$ mesh whereas those of Kanuma area were 17,247 ha and 22,735 , and 7,262 ha and 10,116, respectively. The number of subcompartments on the $50 \mathrm{~m}$ mesh in both areas was significantly less than the actual number of subcompartments because 


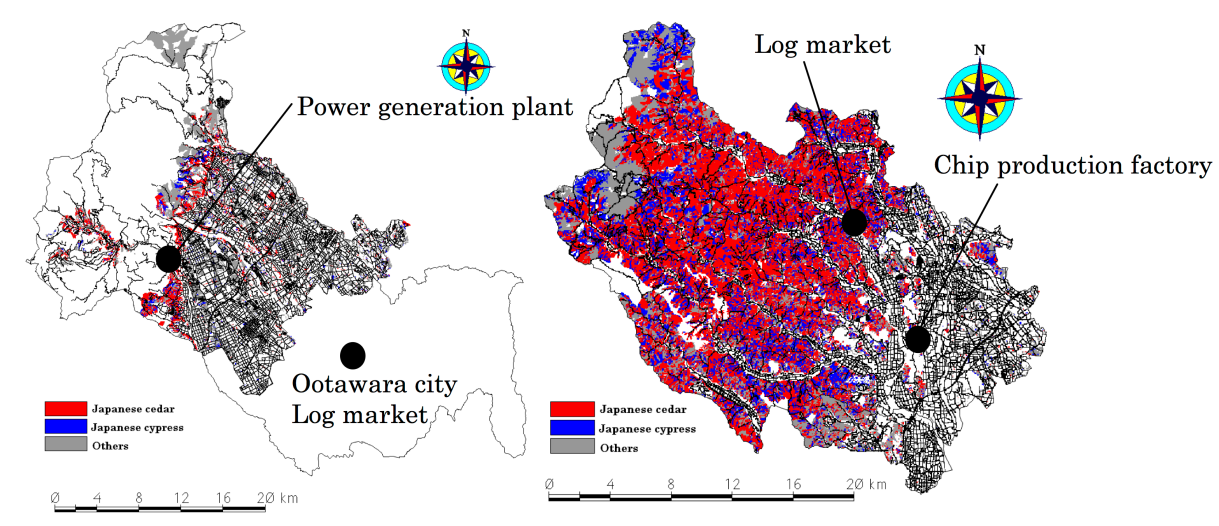

Figure 2. Stand species.

Left of the figure is Nasushiobara city and right is the Kanuma area.

there were many small subcompartments below 0.25 ha that could not be recognized on the $50 \mathrm{~m}$ mesh. Nonetheless, the actual area was not significantly reduced.

\section{Methods}

In this study, we estimated the production forests and annual available amount of forest biomass resources based on the profitable subcompartments in the following order: 1) estimation of the supply potential of timber and logging residue based on the cutting and extraction rates of thinning and final-felling operations during a 60-year rotation; 2) estimation of total expenses from planting to final-felling operations; 3 ) estimation of revenue from thinning and final-felling operations during a 60-year rotation; 4) estimation of economic balances during a 60-year rotation; 5) extraction of the production forests as profitable subcompartments; and 6) estimation of the annual available amount of forest biomass resources from profitable subcompartments. 


\subsection{Estimating the Supply Potential of Timber and Logging Residues}

Thinning and final-felling operations were assumed to be conducted based on stand ages (Table 1). The supply potential of timber and logging residue on each subcompartment during the 60-year rotation were estimated based on the cutting and extraction rates (Table 1). The stand age, cutting rate $(C r)$, extraction rate $(E r)$, logging residue rate $(L r)$, and timber rate $(T r)$ were set in accordance with the Forest Owners' Association's research report on extracting "forest biomass resources" (2008). Extraction rates $(E r)$ for the second-thinning and final-felling operations were set to $109 \%$ because of top and branch extractions (Aruga et al., 2006a). The logging residue rate $(L r)$ is the ratio of logging residue to be transported to the power generation plant in Nasushiobara city or the chip production factory in Kanuma city to the total felled and extracted volume, whereas the timber rate $(T r)$ is the ratio of timbers to be transported to log markets to the total felled and extracted volume (Figure 2).

Table 1. Harvesting conditions of each operation classified based on stand ages.

\begin{tabular}{lccc}
\hline & $\begin{array}{c}\text { First thinning } \\
\text { (precommercial) }\end{array}$ & $\begin{array}{c}\text { Second thinning } \\
\text { (commercial) }\end{array}$ & $\begin{array}{c}\text { Final felling } \\
\text { (clear cutting) }\end{array}$ \\
\hline Stand age (years) & 25 & 40 & 60 \\
Cutting rate $(C r)$ & $25 \%$ & $35 \%$ & $100 \%$ \\
Extracting rate $(E r)$ & $80 \%$ & $109 \% *$ & $109 \% *$ \\
Logging residue rate $(\mathrm{Lr})$ & $100 \%$ & $55 \%$ & $26 \%$ \\
Timber rate $(T r)$ & $0 \%$ & $45 \%$ & $74 \%$ \\
\hline *Tops and branches extraction & & &
\end{tabular}

Subsequently, the amount of timber and logging residue was estimated using the following equations.

[1] $\quad H=S \times C r \times E r \times A=V \times A$ 
[2] $\quad H_{T}=H \times T r$

[3] $H_{L}=H \times L r$

$H$ is the extracted volume $\left(\mathrm{m}^{3}\right), S$ is the stock of the stems in the forest registration data $\left(\mathrm{m}^{3} / \mathrm{ha}\right), A$ is the area of the subcompartments (ha), $V$ is the extracted volume per hectare $\left(\mathrm{m}^{3} / \mathrm{ha}\right), H_{T}$ is the extracted timber volume $\left(\mathrm{m}^{3}\right)$, and $H_{L}$ is the extracted logging residue volume $\left(\mathrm{m}^{3}\right)$.

\subsection{Estimating the Total Expenses including Regeneration Ex- penses after Final-Felling Operations}

The Forest Owners' Cooperative conducts thinning operations by chainsaw, and extracts thinned woods by mini-forwarder approximately 50 ha annually. However, mechanization is necessary to promote thinning operations and extract thinned woods. This study investigated the conventional and the mechanized operation system. Felling and processing, bunching, forwarding, and transporting of the conventional operation system were conducted by chainsaw, mini grapple loader, mini-forwarder, and truck, respectively, whereas the felling, bunching, processing, forwarding, and transporting in the mechanized operation system were assumed to be conducted by chainsaw, grapple loader, processor, forwarder, and truck. The bucket capacities of the base machine for mini grapple loader, grapple loader, and processor were 0.15, 0.45, and $0.45 \mathrm{~m}^{3}$, respectively. The loading capacities of mini forwarder without grapple-crane and forwarder with grapple-crane were 2.0 tons and 2.8 tons, respectively.

The model also examined three types of forest biomass harvesting systems: 1) normal extraction, which means both timber and forest biomass resources extraction and selling to log markets, the power generation plant, or the chip production factory, 2) landing sale, which means normal timber sale and selling logging residue at landings, and 
3) no biomass extraction, which means precommercial thinning operations for first-thinning operations and only timber extraction for second-thinning and final-felling operations. In the landing sale, the forest owners were assumed to extract and sell the logging residue to and at landings by themselves, and to receive income from the logging residue sale, but not to have income from the extraction operations.

After the operation systems were determined, all costs, such as the direct and indirect operation expenses associated with each machine, strip road and landing establishment expenses, and regeneration expenses, were estimated (Eq.[4]).

$$
A=D+S+L+I+R
$$

$A$ : all costs, $D$ : direct operation expenses, $S$ : strip road establishment expenses, $L$ : landing establishment expenses, $I$ : indirect operation expenses, and $R$ : regeneration expenses.

The direct operation expenses are shown in Table 2, and include labor and machinery expenses (maintenance expenses, management expenses, depreciation expenses, and fuel and oil expenses). Forwarding and transporting costs were changed according to the loading capacity rate for timber and logging residues on first- and second-thinning, and final-felling operations (Table 3). Forwarding distances were estimated as average distances from the landings to all grids within the subcompartments. Landings were set within grids to minimize their distances from the roads, the centers of gravity in the subcompartment, and the power generation plant in Nasushiobara city or the chip production factory in Kanuma city. Transporting distances from the landings to the power generation plant in Nasushiobara city or the chip production factory in Kanuma city, and the log markets were calculated using the shortest path algorithm, i.e., the Dijkstra method (Dijkstra, 1959). If the subcompartments were not near existing roads, the supply potential 
of these subcompartments was not evaluated as the available amounts.

Table 2. Direct operation expenses.

\begin{tabular}{ccccc}
\hline Machine & Operation & Expense $\left(\mathrm{yen} / \mathrm{m}^{3}\right)$ & System & Reference \\
\hline Chainsaw & Felling & $53 / V n+65$ & Both & Nakahata et al., 2011 \\
Chainsaw & Processing & $39 / V l+329$ & Conventional & Nakahata et al., 2011 \\
Processor & Processing & $207 / V l+161$ & Mechanized & Nakahata et al., 2011 \\
Mini grapple-loader & Bunching & 1,999 & Conventional & Nakahata et al., 2011 \\
Grapple-loader & Bunching & 1,199 & Mechanized & Nakahata et al., 2011 \\
Mini forwarder & Forwarding & $(769+0.508 L f) / R f$ & Conventional & Nakahata et al., 2011 \\
Forwarder & Forwarding & $(378+0.301 L f) / R f$ & Mechanized & Nakahata et al., 2011 \\
Truck & Transporting & $(778+0.031 L t) / R t$ & Both & Sawaguchi, 1996 \\
\hline
\end{tabular}

$V n$ is the stem volume $\left(\mathrm{m}^{3} / \mathrm{stem}\right), V l$ is the extracted volume per stem $\left(\mathrm{m}^{3} / \mathrm{stem}\right), L f$ is forwarding distance $(\mathrm{m}), L t$ is the transporting distance $(\mathrm{m}), R f$ and $R t$ are the loading capacity rate shown in Table 3 .

Table 3. Loading capacity rate.

\begin{tabular}{cccc}
\hline & $\begin{array}{c}\text { First thinning } \\
\text { (Biomass) }\end{array}$ & $\begin{array}{c}\text { Second thinning } \\
\text { Final felling } \\
\text { (Biomass) }\end{array}$ & $\begin{array}{c}\text { Second thinning } \\
\text { Final felling } \\
\text { (Timber) }\end{array}$ \\
\hline$R f$ & 1.00 & 0.51 & 1.06 \\
$R t$ & 0.94 & 0.49 & 1.00 \\
\hline
\end{tabular}

Strip roads were assumed to be established for forwarding operations. Strip-road density, $d(\mathrm{~m} / \mathrm{ha})$ was related to the average slope angle of each subcompartment, $\theta$ (degree) in Figure 3:

$$
d=956.72 \theta^{-0.52}
$$

Then, strip-road costs, $S$ (yen), were estimated by multiplying the strip-road density, $d(\mathrm{~m} /$ ha) with the following unit strip-road costs, $s$ (yen $/ \mathrm{m})$ :

[6] $s=67 e^{0.116 \theta}$ for the conventional operation system,

[7] $s=220 e^{0.117 \theta}$ for the mechanized operation system

(Sawaguchi, 1996).

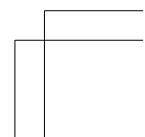




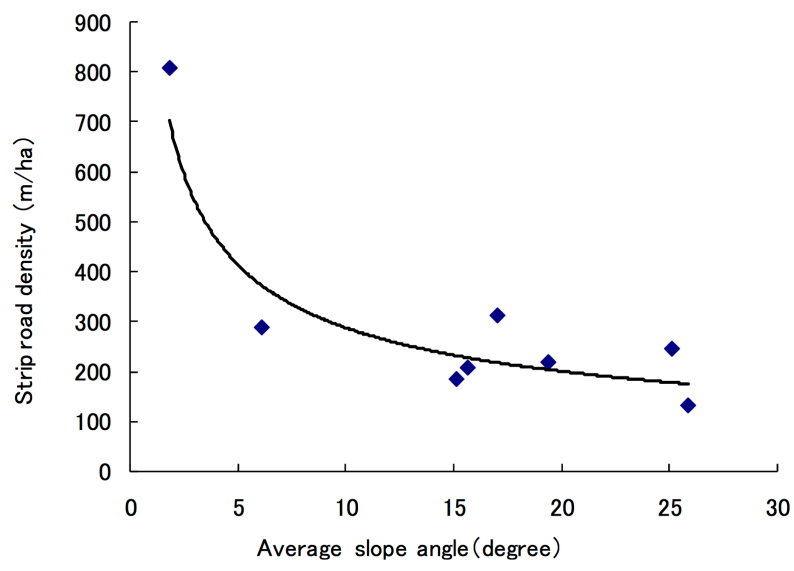

Figure 3. Average slope angle and strip road density.

Landing-establishment expenses, $L$ (yen) were estimated with the following equation generated from landing areas and landingestablishment productivity (Zenkoku Ringyo Kairyo Fukyu Kyokai, 2001), and a machinery expense of back-hoe which was assumed to be the same with grapple loader:

[8] $\quad L=187.63 \mathrm{~V}$

Machine transportation expenses, garage maintenance expenses, incidental personnel expenses, overhead costs, and handling fees associated with the log market were considered as indirect operation expenses. Machine transportation expenses were estimated by unit costs, 50,000 yen/machine (Zenkoku Ringyo Kairyo Fukyu Kyokai, 2001), and the number of machines, which were two, a mini grapple loader and miniforwarder in the conventional operation system, and three, a grapple loader, a processor, and a forwarder in the mechanized operation system. 
Garage maintenance expenses were estimated to 2,000 yen/machine/day. Incidental personnel expenses were estimated as $55 \%$ of the direct personnel expenses. Overhead costs were estimated as $20 \%$ of the direct operation costs. Handling fees associated with the $\log$ market were estimated with piling costs as $700 \mathrm{yen} / \mathrm{m}^{3}$ and $10 \%$ of the timber prices $\left(\mathrm{yen} / \mathrm{m}^{3}\right)$.

In addition to the timber and forest biomass extraction costs, the regeneration expenses including site preparation, planting, weeding, vine cutting, pruning, and forest inventory were considered. The regeneration expenses were estimated at 2,512,376 yen/ha for Japanese cedar and 2,892,365 yen/ha for Japanese cypress (Okawabata, 2003).

On normal extraction of the first-thinning operations, only logging residue (thinned woods left in the forest) after precommercial thinning operations were extracted as forest biomass resources. Therefore, all costs were for logging residues extraction (Table 4). The logging residue was considered as a by-product of timber harvesting on secondthinning and final-felling operations. Therefore, operations for logging residue extraction started after processing and all costs, excluding logging residue extraction and associated indirect costs, were considered as timber extraction costs. On the landing sale of the first-thinning operations, only felling, processing, and associated indirect costs were considered. Extraction costs and associated indirect costs were not considered because income was assumed to come from the logging residues sale, but not from the extraction operations. On no extraction of biomass in first-thinning (precommercial thinning) operations, only felling costs and associated indirect costs were considered, but processing and extraction costs, and associated indirect costs were not considered. 
Table 4. Cost estimation.

\begin{tabular}{|c|c|c|c|c|c|c|c|c|c|c|c|c|c|c|c|c|c|c|}
\hline & \multicolumn{6}{|c|}{ Normal extraction } & \multicolumn{5}{|c|}{ Landing sale } & & \multicolumn{6}{|c|}{ No biomass extraction } \\
\hline & 1 & & 2 & & 3 & & 1 & & 2 & & 3 & & 1 & & 2 & & 3 & \\
\hline & $\mathrm{T}$ & $\mathrm{L}$ & $\mathrm{T}$ & $\mathrm{L}$ & $\mathrm{T}$ & $\mathrm{L}$ & $\mathrm{T}$ & $\mathrm{L}$ & $\mathrm{T}$ & $\mathrm{L}$ & $\mathrm{T}$ & $\mathrm{L}$ & $\mathrm{T}$ & $\mathrm{L}$ & $\mathrm{T}$ & $\mathrm{L}$ & $\mathrm{T}$ & $\mathrm{L}$ \\
\hline Felling & & $\mathrm{X}$ & $\mathrm{X}$ & & $\mathrm{X}$ & & & $\mathrm{X}$ & $\mathrm{X}$ & & $\mathrm{X}$ & & & $\mathrm{X}$ & $\mathrm{X}$ & & $\mathrm{X}$ & \\
\hline Processing & & $\mathrm{X}$ & $\mathrm{X}$ & & $\mathrm{X}$ & & & $\mathrm{X}$ & $\mathrm{X}$ & & $\mathrm{X}$ & & & & $\mathrm{X}$ & & $\mathrm{X}$ & \\
\hline Bunching & & $\mathrm{X}$ & $\mathrm{X}$ & $\mathrm{X}$ & $\mathrm{X}$ & $\mathrm{X}$ & & & $\mathrm{X}$ & & $\mathrm{X}$ & & & & $\mathrm{X}$ & & $\mathrm{X}$ & \\
\hline Forwarding & & $\mathrm{X}$ & $\mathrm{X}$ & $\mathrm{X}$ & $\mathrm{X}$ & $\mathrm{X}$ & & & $\mathrm{X}$ & & $\mathrm{X}$ & & & & $\mathrm{X}$ & & $\mathrm{X}$ & \\
\hline Transporting & & $\mathrm{X}$ & $\mathrm{X}$ & $\mathrm{X}$ & $\mathrm{X}$ & $\mathrm{X}$ & & & $\mathrm{X}$ & & $\mathrm{X}$ & & & & $\mathrm{X}$ & & $\mathrm{X}$ & \\
\hline Landing-establishment & & $\mathrm{X}$ & $\mathrm{X}$ & & $\mathrm{X}$ & & & & $\mathrm{X}$ & & $\mathrm{X}$ & & & & $\mathrm{X}$ & & $\mathrm{X}$ & \\
\hline Machine transportation & & $\mathrm{X}$ & $\mathrm{X}$ & & $\mathrm{X}$ & & & & $\mathrm{X}$ & & $\mathrm{X}$ & & & & $\mathrm{X}$ & & $\mathrm{X}$ & \\
\hline Garage-maintenance & & $\mathrm{X}$ & $\mathrm{Y}$ & $\mathrm{Y}$ & Y & $\mathrm{Y}$ & & & $\mathrm{X}$ & & $\mathrm{X}$ & & & & $\mathrm{X}$ & & $\mathrm{X}$ & \\
\hline Incidental personnel & & $\mathrm{X}$ & $\mathrm{Y}$ & $\mathrm{Y}$ & $\mathrm{Y}$ & Y & & $\mathrm{X}$ & $\mathrm{X}$ & & $\mathrm{X}$ & & & $\mathrm{X}$ & $\mathrm{X}$ & & $\mathrm{X}$ & \\
\hline Overhead costs & & $\mathrm{X}$ & $\mathrm{Y}$ & $\mathrm{Y}$ & $\mathrm{Y}$ & $\mathrm{Y}$ & & $\mathrm{X}$ & $\mathrm{X}$ & & $\mathrm{X}$ & & & $\mathrm{X}$ & $\mathrm{X}$ & & $\mathrm{X}$ & \\
\hline Handling fees & & & $\mathrm{X}$ & & $\mathrm{X}$ & & & & $\mathrm{X}$ & & $\mathrm{X}$ & & & & $\mathrm{X}$ & & $\mathrm{X}$ & \\
\hline
\end{tabular}

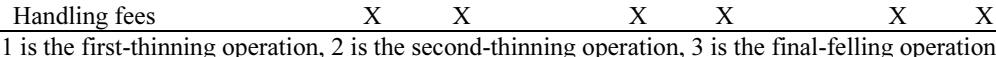

$\mathrm{T}$ is for timber, $\mathrm{L}$ is for logging residue.

$\mathrm{X}$ is for the whole cost consideration, $\mathrm{Y}$ is the cost consideration according to timber and logging residues volumes.

\subsection{Estimating Revenue from Thinning and Final-Felling Op- erations during 60-year Rotation}

Income was estimated using the supply potential and log prices: 11,000 yen $/ \mathrm{m}^{3}$ for Japanese cedar and 22,000 yen $/ \mathrm{m}^{3}$ for Japanese cypress, and for forest biomass resources, $3,400 \mathrm{yen} / \mathrm{m}^{3}$ for normal extraction and 1,000 yen $/ \mathrm{m}^{3}$ for landing sale.

For thinning operations, subsidies were estimated with standard unit prices, areas, assessment coefficients, and the subsidy rate of the Tochigi Prefectural Government (2010b). The subsidy on first-thinning operations for normal extraction was 235,504 yen/ha, the subsidy on the first-thinning operations for landing sale and no biomass extraction was 64,291 yen/ha, and the subsidy on second-thinning operations for all types of operations was 338,188 yen/ha. The subsidies for strip road establishment (Table 5) were also estimated with standard unit prices, length, assessment coefficients, and the subsidy rate of the Tochigi Prefectural Government (2010b). 
Table 5. Subsidies for strip road establishment (yen/m).

\begin{tabular}{ccc}
\hline Average slope angle (degree) & Conventional & Mechanized \\
\hline 5 & 40 & 159 \\
10 & 60 & 191 \\
15 & 91 & 230 \\
20 & 137 & 276 \\
25 & 147 & 477 \\
30 & 183 & 850 \\
\hline
\end{tabular}

This study also considered the subsidy for regeneration. Like thinning operations, subsidies were estimated with standard unit prices, areas, assessment coefficients, and the subsidy rate of the Tochigi Prefectural Government (2010b). The subsidies were estimated at 1,227,400 yen/ha for Japanese cedar and 1,219,240 yen/ha for Japanese cypress.

\subsection{Extracting Production Forests as Profitable Subcompart- ments.}

After economic balances were estimated with income and costs during the 60 -year rotation, the production forests were extracted as profitable subcompartments. Then, the annual available amount of forest biomass resources was estimated as the supply potential from profitable subcompartments.

\section{Results and Discussion}

The supply potential of timber and logging residue was 1,572,395 $\mathrm{m}^{3}$ and $972,672 \mathrm{~m}^{3}$ in Nasushiobara city (Table 6), and 12,587,431 $\mathrm{m}^{3}$ and $7,868,852 \mathrm{~m}^{3}$ in the Kanuma area for 60 years (Table 7). Therefore, the annual supply potential of timber and logging residue were 26,207 $\mathrm{m}^{3}$ /year and 16,211 $\mathrm{m}^{3} /$ year in Nasushiobara city, and 209,791 $\mathrm{m}^{3} /$ year and 131,148 $\mathrm{m}^{3}$ /year in Kanuma area, respectively. The annual supply potential of timber, $26,207 \mathrm{~m}^{3}$ /year, was over the planned harvesting coniferous tree volumes in Nasushiobara city, 25,700 m³/year, (Tochigi 
Prefecture Government, 2011). The annual supply potential of logging residue of $16,211 \mathrm{~m}^{3}$ /year in Nasushiobara city was 2.7 times the annual demand of the planned woody biomass power generation plant of $6,000 \mathrm{~m}^{3} /$ year (Nakahata et al., 2011). Conversely, the annual supply potential of timber in the Kanuma area of $209,791 \mathrm{~m}^{3} /$ year was 5.7 times the planned harvesting coniferous tree volume of $36,600 \mathrm{~m}^{3} /$ year (Tochigi Prefecture Government, 2010c). The annual supply potential of the logging residue in the Kanuma area of $131,148 \mathrm{~m}^{3}$ /year was 10.9 times of the annual production of chips at the chip production factory in Kanuma city of 12,000 m³ /year (Shimotsuke newspaper, 2009).

The most economical timber and forest biomass harvesting system for each sub-compartment could be classified as being one of the seven types of systems illustrated in Figure 4. The most common type for the final felling operation was the mechanized operation system with landing sales. For the second thinning operation, the most common type was the conventional or mechanized operation system with landing sales. In contrast, the most common type for the first thinning operation was the conventional operation system with normal extraction or landing sales. When the most economical timber and forest biomass harvesting system for each subcompartment was applied, the number of profitable, nonprofitable, and roadless subcompartments was 1,801; 1,625; and 2,330 of the total 5,756 subcompartments in Nasushiobara city whereas they were 8,$940 ; 3,014$; and 20,897 of the total 32,851 subcompartments in the Kanuma area (Table 8 and Figure 5).

Then, the annual available amount of forest biomass resources was estimated as the annual supply potential of the profitable subcompartments. The available amount of timber and logging residue was 754,524 $\mathrm{m}^{3}$ and 468,299 $\mathrm{m}^{3}$ in Nasushiobara city (Table 6), and 4,826,605 $\mathrm{m}^{3}$ and $3,018,756 \mathrm{~m}^{3}$ in the Kanuma area during 60 years (Table 7). Therefore, the annual available amount of timber and logging 
Table 6. Supply potentials and available amount of timber and forest biomass resources in Nasushiobara city $\left(\mathrm{m}^{3}\right)$.

\begin{tabular}{|c|c|c|c|}
\hline & \multicolumn{3}{|c|}{ Supply Potential } \\
\hline & Timber & Biomass & Total \\
\hline First Thinning & 0 & 182,561 & 182,561 \\
\hline Second Thinning & 211,657 & 281,187 & 492,844 \\
\hline Final Felling & $1,360,737$ & 508,925 & $1,869,662$ \\
\hline Total & $1,572,395$ & 972,672 & $2,545,067$ \\
\hline \multirow[t]{3}{*}{ Annual } & 26,207 & 16,211 & 42,418 \\
\hline & \multicolumn{3}{|c|}{ Available Amounts Including Regeneration } \\
\hline & Timber & Biomass & Total \\
\hline First Thinning & 0 & 88,572 & 88,572 \\
\hline Second Thinning & 102,180 & 135,746 & 237,925 \\
\hline Final Felling & 652,344 & 243,981 & 896,325 \\
\hline Total & 754,524 & 468,299 & $1,222,823$ \\
\hline \multirow[t]{3}{*}{ Annual } & 12,575 & 7,805 & 20,380 \\
\hline & \multicolumn{3}{|c|}{ Available Amounts Excluding Regeneration } \\
\hline & Timber & Biomass & Total \\
\hline First Thinning & 0 & 113,598 & 113,598 \\
\hline Second Thinning & 131,725 & 174,996 & 306,721 \\
\hline Final Felling & 846,572 & 316,623 & $1,163,195$ \\
\hline Total & 978,296 & 605,218 & $1,583,514$ \\
\hline Annual & 16,305 & 10,087 & 26,392 \\
\hline
\end{tabular}

residue was $12,575 \mathrm{~m}^{3}$ /year and $7,805 \mathrm{~m}^{3}$ /year in Nasushiobara city, and $80,443 \mathrm{~m}^{3} /$ year and $50,313 \mathrm{~m}^{3} /$ year in the Kanuma area, respectively. The annual available amount of timber of $12,575 \mathrm{~m}^{3} /$ year was half the planned coniferous tree-harvesting volume in Nasushiobara city of 25,700 $\mathrm{m}^{3} /$ year (Tochigi Prefecture Government, 2011). The annual available amount of logging residue of $7,805 \mathrm{~m}^{3} /$ year in Nasushiobara city was over the annual demand of the planned woody biomass power generation plant of $6,000 \mathrm{~m}^{3} /$ year (Nakahata et al., 2011). Conversely, the annual available amount of timber in the Kanuma area of 80,443 
Table 7. Supply potentials and available amount of timber and forest biomass resources in Kanuma area $\left(\mathrm{m}^{3}\right)$.

\begin{tabular}{|c|c|c|c|}
\hline & \multicolumn{3}{|c|}{ Supply Potential } \\
\hline & Timber & Biomass & Total \\
\hline First Thinning & 0 & $1,526,346$ & $1,526,346$ \\
\hline Second Thinning & $1,712,658$ & $2,275,270$ & $3,987,928$ \\
\hline Final Felling & $10,874,773$ & $4,067,236$ & $14,942,010$ \\
\hline Total & $12,587,431$ & $7,868,852$ & $20,456,283$ \\
\hline \multirow[t]{3}{*}{ Annual } & 209,791 & 131,148 & 340,938 \\
\hline & \multicolumn{3}{|c|}{ Available Amounts Including Regeneration } \\
\hline & Timber & Biomass & Total \\
\hline First Thinning & 0 & 586,868 & 586,868 \\
\hline Second Thinning & 656,583 & 872,272 & $1,528,854$ \\
\hline Final Felling & $4,170,022$ & $1,559,616$ & $5,729,638$ \\
\hline Total & $4,826,605$ & $3,018,756$ & $7,845,360$ \\
\hline \multirow[t]{3}{*}{ Annual } & 80,443 & 50,313 & 130,756 \\
\hline & \multicolumn{3}{|c|}{ Available Amounts Excluding Regeneration } \\
\hline & Timber & Biomass & Total \\
\hline First Thinning & 0 & 642,282 & 642,282 \\
\hline Second Thinning & 719,907 & 956,398 & $1,676,305$ \\
\hline Final Felling & $4,581,161$ & $1,713,384$ & $6,294,545$ \\
\hline Total & $5,301,068$ & $3,312,064$ & $8,613,132$ \\
\hline Annual & 88,351 & 55,201 & 143,552 \\
\hline
\end{tabular}

$\mathrm{m}^{3} /$ year was 2.2 times of the planned coniferous tree-harvesting volume of $36,600 \mathrm{~m}^{3} /$ year (Tochigi Prefecture Government, 2010c). The annual available amount of logging residue in the Kanuma area of 50,313 $\mathrm{m}^{3}$ /year was 4.2 times the annual production of chips at the chip production factory in Kanuma city of 12,000 $\mathrm{m}^{3} /$ year (Shimotsuke newspaper, 2009).

\subsection{Regeneration Costs}

The number of profitable subcompartments increased without considering the regeneration costs (Table 8). This showed the current situation of Japanese forestry where many forest owners are not willing 
Table 8 . The number and area of subcompartments.

\begin{tabular}{|c|c|c|c|c|}
\hline & \multicolumn{4}{|c|}{ Nasushiobara city } \\
\hline & \multicolumn{2}{|c|}{ Including Regeneration } & \multicolumn{2}{|c|}{ Excluding Regeneration } \\
\hline & $\begin{array}{c}\text { No. Sub- } \\
\text { compartment }\end{array}$ & $\begin{array}{c}\text { Area } \\
\text { (ha) }\end{array}$ & $\begin{array}{c}\text { No. Sub- } \\
\text { compartment }\end{array}$ & $\begin{array}{c}\text { Area } \\
\text { (ha) }\end{array}$ \\
\hline Profitable & 1,801 & $1,787.75$ & 3,384 & $2,304.00$ \\
\hline Deficit & 1,625 & 527.00 & 42 & 10.75 \\
\hline Roadless & 2,330 & $1,364.25$ & 2,330 & $1,364.25$ \\
\hline \multirow[t]{4}{*}{ Total } & 5,756 & $3,679.00$ & 5,756 & $3,679.00$ \\
\hline & \multicolumn{4}{|c|}{ Kanuma area } \\
\hline & \multicolumn{2}{|c|}{ Including Regeneration } & \multicolumn{2}{|c|}{ Excluding Regeneration } \\
\hline & $\begin{array}{c}\text { No. Sub- } \\
\text { compartment }\end{array}$ & $\begin{array}{c}\text { Area } \\
\text { (ha) }\end{array}$ & $\begin{array}{c}\text { No. Sub- } \\
\text { compartment }\end{array}$ & $\begin{array}{c}\text { Area } \\
\text { (ha) }\end{array}$ \\
\hline Profitable & 8,940 & $9,070.00$ & 11,888 & $9,941.75$ \\
\hline Deficit & 3,014 & 888.25 & 66 & 16.50 \\
\hline Roadless & 20,897 & $14,551.00$ & 20,897 & $14,551.00$ \\
\hline Total & 32,851 & $24,509.25$ & 32,851 & $24,509.25$ \\
\hline
\end{tabular}

to conduct regeneration operations after final felling.

Similar to the number of subcompartments, the available amount of timber and logging residue without considering the regeneration costs increased to $978,296 \mathrm{~m}^{3}$ and $605,218 \mathrm{~m}^{3}$ in Nasushiobara city (Table 6 ) and $5,301,068 \mathrm{~m}^{3}$ and $3,312,064 \mathrm{~m}^{3}$ in the Kanuma area for 60 years (Table 7 ). Therefore, the annual available amount of timber and logging residue also increased to $16,305 \mathrm{~m}^{3} /$ year and $10,087 \mathrm{~m}^{3} /$ year in Nasushiobara city, and 88,351 $\mathrm{m}^{3}$ /year and $55,201 \mathrm{~m}^{3} /$ year in the Kanuma area, respectively. It is important to develop low-cost regeneration operations after final felling or to extent the rotation ages while reducing the number of regeneration operations for sustainable forest management and sustainable use of forest biomass resources in Japan. 


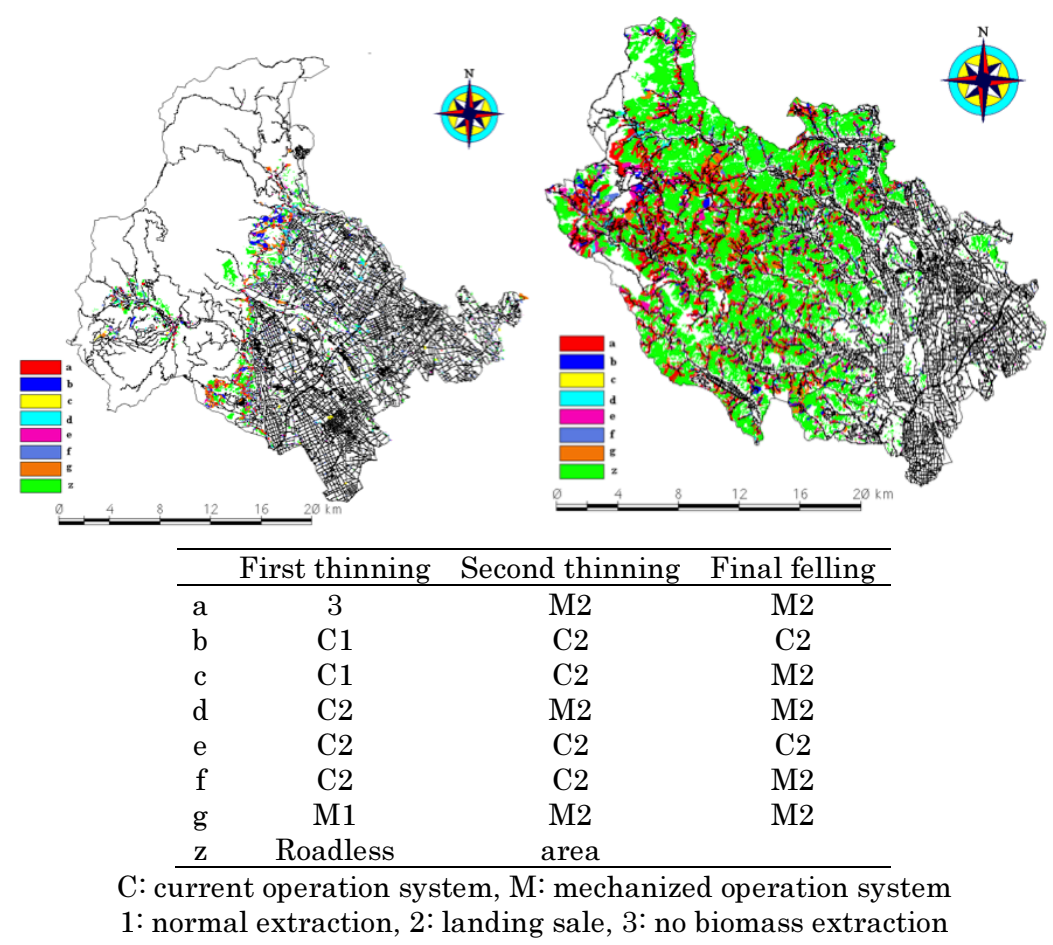

Figure 4. The most economical timber and forest biomass harvesting system for each sub-compartment.

Left of the figure is Nasushiobara city and right is the Kanuma area.

\subsection{Forest Road Network}

The number of roadless subcompartments was 2,330 and 20,897 in Nasushiobara city and the Kanuma area, respectively, which represents $40 \%$ and $64 \%$ of the total number of subcompartment in these areas (Table 8). Therefore, it is expected to increase the annual available amount of logging residue by establishing forest road networks. In this section, forest road networks were planned to connect landings, which were not near existing roads by the Dijkstra method using the 


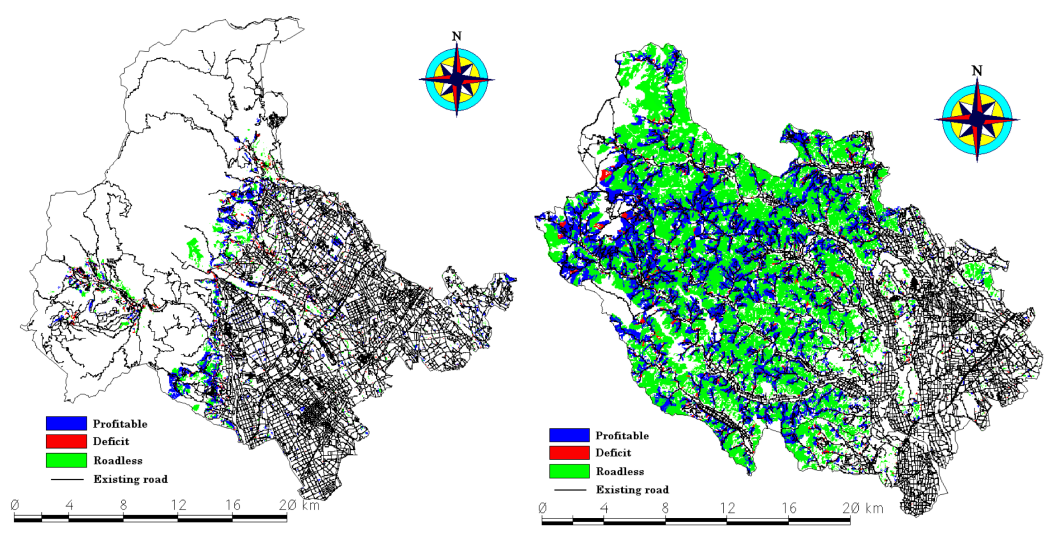

Figure 5. Profitable subcompartments including regeneration cost.

Left of the figure is Nasushiobara city and right is the Kanuma area.

closest neighboring roads (Figure 6). Forest road networks should be established by public funds. Therefore, the expenses for forest road establishment were not considered in this section.

The number of profitable and nonprofitable subcompartments was 2,879 and 2,877 of the total number of subcompartment $(5,756)$ in Nasushiobara city whereas in the Kanuma area they were 23,551 and 9,300, respectively, (Table 9). The number of profitable subcompartments significantly increased in both areas. The annual available amount of timber and logging residue also increased to $19,084 \mathrm{~m}^{3} /$ year and 11,849 $\mathrm{m}^{3}$ /year in Nasushiobara city (Table 10), and $184,019 \mathrm{~m}^{3} /$ year and $115,213 \mathrm{~m}^{3}$ /year in the Kanuma area (Table 11), respectively. However, the road density of Nasushiobara city and the Kanuma area was $43.5 \mathrm{~m} / \mathrm{ha}$ and $87.0 \mathrm{~m} / \mathrm{ha}$, respectively, after the establishment of the forest road network. The cost of establishing a high-density forest road network in the Kanuma area would be too much, because of the many roadless subcompartments in the area.

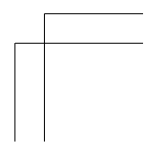




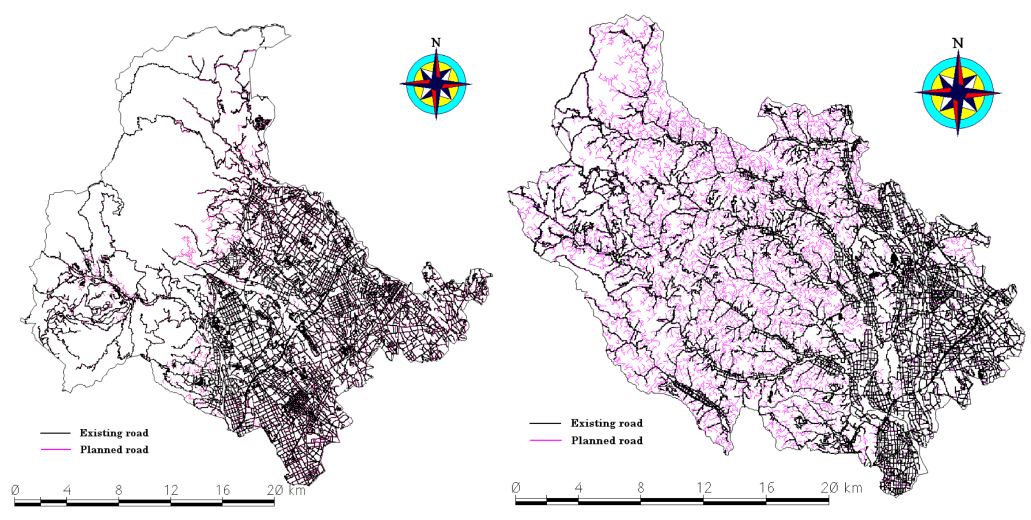

Figure 6. Forest road network establishment based on subcompartments.

Left of the figure is Nasushiobara city and right is the Kanuma area.

\subsection{Extending Forestry Operation Sites while Merging Sub- compartments}

Since all indirect costs were fixed, the smaller the volume, the higher the cost. Therefore, cost reductions are expected by extending forestry operation sites while merging subcompartments. Forest road establishment expenses are expected to decrease because the number of landings, which were not near existing roads and should be connected, also decreased in this study assuming a landing in each operation site. In this section, extending forestry operation sites was considered while merging subcompartments in the same watersheds. As a result, the number of subcompartments, 5,756, was reduced to the number of extended forestry operation sites, 1,519 , in Nasushiobara city while the number of subcompartments, 32,851 , was reduced to the number of extended forestry operation sites, 1,237 , in the Kanuma area. The average area of subcompartments, 0.64 ha, was increased to the average area of the 
Table 9. The number and area of subcompartments and extended operation sites.

\begin{tabular}{lrrrr}
\hline \multicolumn{5}{c}{ Nasushiobara city } \\
\hline & \multicolumn{5}{c}{ Forest road } & \multicolumn{2}{c}{ Extended sites } \\
\hline & $\begin{array}{c}\text { No. Sub- } \\
\text { compartment }\end{array}$ & \multicolumn{1}{c}{$\begin{array}{c}\text { Area } \\
\text { (ha) }\end{array}$} & $\begin{array}{c}\text { No. } \\
\text { extended sites }\end{array}$ & $\begin{array}{c}\text { Area } \\
\text { (ha) }\end{array}$ \\
\hline Profitable & 2,879 & $2,718.25$ & 1,456 & $3,645.50$ \\
Deficit & 2,877 & 960.75 & 63 & 33.50 \\
Roadless & 0 & 0.00 & 0 & 0.00 \\
\hline Total & 5,756 & $3,679.00$ & 1,519 & $3,679.00$ \\
\hline \multicolumn{5}{c}{ Kanuma area } \\
\hline \multicolumn{5}{c}{ Extended sites } \\
\hline \multicolumn{5}{c}{ Forest road } \\
\hline No. Sub- & Area & No. & Area \\
& compartment & (ha) & Extended sites & (ha) \\
\hline Profitable & 23,551 & $21,689.50$ & 1,237 & $24,509.25$ \\
Deficit & 9,300 & $2,819.75$ & 0 & 0.00 \\
Roadless & 0 & 0.00 & 0 & 0.00 \\
\hline Total & 32,851 & $24,509.25$ & 1,237 & $24,509.25$ \\
\hline \multicolumn{5}{c}{0}
\end{tabular}

extended forestry operation sites, 2.42 ha, in Nasushiobara city while the average area of the subcompartments, 0.75 ha, was increased to the average area of the extended forestry operation sites, $19.81 \mathrm{ha}$, in the Kanuma area. The road density of Nasushiobara city and Kanuma area was $30.8 \mathrm{~m} / \mathrm{ha}$ and $26.4 \mathrm{~m} / \mathrm{ha}$, respectively, after the establishment of forest road network based on the extended forestry operation sites (Figure 7). The road network density was similar to the target density in Japan.

The number of profitable and nonprofitable extended forestry operation sites was 1,456 and 63 of the total 1,519 extending forestry operation sites in Nasushiobara city (Table 9). In the Kanuma area, all of the 1,237 extending forestry operation sites were profitable. Therefore, the annual available amount of timber and logging residue in the 
Table 10. Available amount of timber and forest biomass resources in Nasushiobara city $\left(\mathrm{m}^{3}\right)$.

\begin{tabular}{|c|c|c|c|}
\hline & \multicolumn{3}{|c|}{ Forest road network } \\
\hline & Timber & Biomass & Total \\
\hline First Thinning & 0 & 134,549 & 134,549 \\
\hline Second Thinning & 155,163 & 206,134 & 361.297 \\
\hline Final Felling & 989,899 & 370,229 & $1,360,128$ \\
\hline Total & $1,145,062$ & 710,912 & $1,855,975$ \\
\hline \multirow[t]{3}{*}{ Annual } & 19,084 & 11,849 & 30,933 \\
\hline & \multicolumn{3}{|c|}{ Extended operation site } \\
\hline & Timber & Biomass & Total \\
\hline First Thinning & 0 & 181,285 & 181,285 \\
\hline Second Thinning & 210,103 & 279,123 & 489,226 \\
\hline Final Felling & $1,350,360$ & 505,044 & $1,855,404$ \\
\hline Total & $1,560,608$ & 965,306 & $2,525,915$ \\
\hline Annual & 26,010 & 16,088 & 42,099 \\
\hline
\end{tabular}

Kanuma area were the same with an annual supply potential of 209,791 $\mathrm{m}^{3}$ /year and 131,148 $\mathrm{m}^{3}$ /year, respectively, (Table 11). The annual available amount of timber and forest biomass resources in Nasushiobara city also increased to $26,010 \mathrm{~m}^{3}$ /year and 16,088 $\mathrm{m}^{3} /$ year (Table 10), respectively.

\section{Conclusions}

The purpose of this study was to develop a model to estimate the annual available amount of forest biomass resources under profitable forest management in Nasushiobara city and the Kanuma area of Tochigi prefecture, Japan. As a result, the number of profitable, nonprofitable, and roadless subcompartments were 1,$801 ; 1,625$; and 2,330, respectively, of the total 5,756 subcompartments in Nasushiobara city whereas they were 8,$940 ; 3,014$; and 20,897 of the total 32,851 subcompartments in the Kanuma area. The annual available amount of forest biomass re- 
Table 11. Available amount of timber and forest biomass resources in Kanuma area $\left(\mathrm{m}^{3}\right)$.

\begin{tabular}{lrrr}
\hline & \multicolumn{3}{c}{ Forest road network } \\
\hline & \multicolumn{1}{c}{ Timber } & Biomass & \multicolumn{1}{c}{ Total } \\
\hline First Thinning & 0 & $1,345,625$ & $1,345,625$ \\
Second Thinning & $1,506,232$ & $2,001,033$ & $3,507,264$ \\
Final Felling & $9,534,935$ & $3,566,128$ & $13,101,063$ \\
\hline Total & $11,041,167$ & $6,912,785$ & $17,953,952$ \\
Annual & 184,019 & 115,213 & 299,233 \\
\hline \multicolumn{4}{c}{ Extended operation site } \\
\hline \multicolumn{4}{c}{ Biomass } \\
\hline \multicolumn{4}{c}{ Total } \\
\hline First Thinning & Timber & $1,526,346$ & $1,526,346$ \\
Second Thinning & $1,712,658$ & $2,275,270$ & $3,987,928$ \\
Final Felling & $10,874,773$ & $4,067,236$ & $14,942,010$ \\
\hline Total & $12,587,431$ & $7,868,852$ & $20,456,283$ \\
Annual & 209,791 & 131,148 & 340,938 \\
\hline \multicolumn{3}{c}{}
\end{tabular}

sources was $7,805 \mathrm{~m}^{3} /$ year and $50,313 \mathrm{~m}^{3} /$ year in Nasushiobara city and the Kanuma area, respectively. The annual available amount of forest biomass resources meets the annual demand of a $500 \mathrm{~kW}$ woody biomass power generation plant planned in Nasushiobara city and the annual production of a chip production factory in the Kanuma area, respectively.

This study just estimated the annual available amount of forest biomass resources with total revenues and costs during the 60-year rotation. However, the estimation should be conducted with considering the current situation of forest resources, forestry, forest and energy industries and projecting their future situation while discounting the future revenues and costs to the present net values although this study did not. The Japan Forest Agency has conducted a measure on the long-term rotation management because revenues from final-felling operations could not cover the regeneration costs under the current 


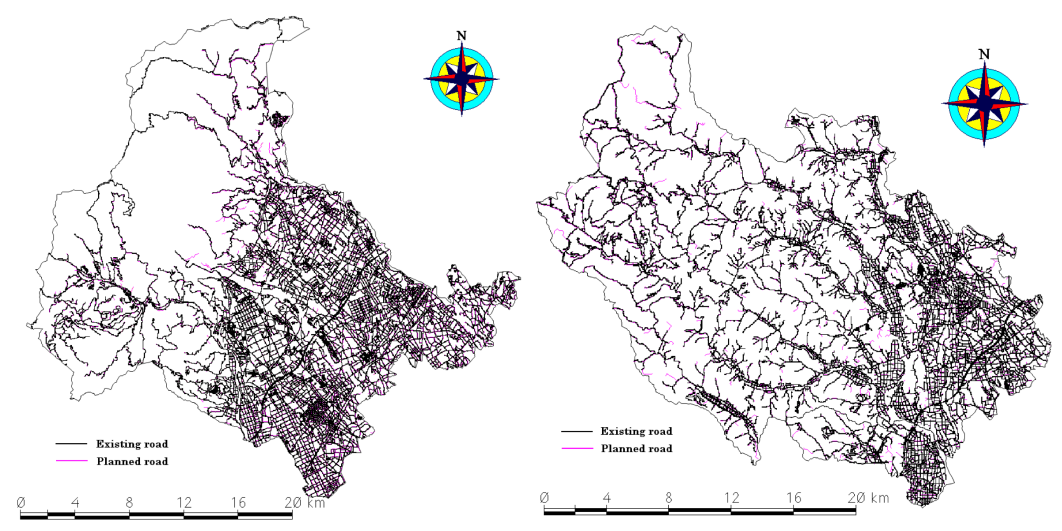

Figure 7. Forest road network extablishment based on the extended forestry operation sites.

Left of the figure is Nasushiobara city and right is the Kanuma area.

conditions. Extending the cutting ages is expected to increase revenue. However, this study did not consider the effect of changing the log prices along with log quality; it will be analyzed in our next study. Establishing the forest road network and extending the forestry operation sites by merging the small subcompartments was also examined. However, this study did not examine how to establish the forest road network and to extend the forestry operation sites. A next study will estimate the annual available amount of forest biomass resources while planning to establish the forest road network and to extend the forestry operation sites. In addition, the study will also examine the results and plans that may decrease the cost.

\section{Acknowledgement}

We are grateful to the Tochigi Prefecture Government for providing the required data. This study was supported by Nissei Zaidan. 


\section{References}

Agency for Natural Resources and Energy (2012) Settlement of the details of the Feed-in Tariff scheme for renewable energy, including purchase price and surcharge rate, <http://www.meti.go.jp/ english/press/2012/0618_01.html> (Accessed June 18, 2012)

Aruga, K., Yoshioka, T. and Sakurai, R. (2006a) Long-term feasibility of timber and forest biomass resources at an intermediate and mountainous area-Balance of harvesting volumes using random search, $J$. Jpn. Forest Eng. Soc. 21: 49-59 (in Japanese with English summary).

Aruga, K., Tasaka, T., Yoshioka, T., Sakurai, R. and Kobayashi, H. (2006b) Long-term feasibility of timber and forest biomass resources at an intermediate and mountainous area (2)-Examining the optimum scale of an energy plant, J. Jpn. Forest Eng. Soc. 21: 185-192 (in Japanese with English summary).

Dijkstra, E. W. (1959) A note on two problems in connection with graphs, Numer. Math. 1: 269-271.

Iuchi, M. (2004) Development of the support system for biomass energy business plans-the data base and evaluation models to simulate the collection cost, Socio-economic research center, Y03023: 1-26 (in Japanese with English summary).

Kamimura, K., Kuboyama, H. and Yamamoto, K. (2009) Estimation of spatial distribution on wood biomass supply potential for three prefectures in the northern Tohoku Region, J. Jpn. Inst. Energ., 88: 877-883 (in Japanese with English Summary).

Kinoshita, T., Inoue, K., Iwao, K., Kagemoto, H. and Yamagata, Y. (2009) A spatial evaluation of forest biomass usage using GIS, Appl. Energ., 86: 1-8.

Kinoshita, T., Ohki, T., and Yamagata, Y. (2010) Woody biomass supply potential for thermal power plants in Japan, Appl. Energ. 
87: 2923-2927.

Mikamo Forest Owners' Association and Sumitomo Osaka Cement Company (2008) Research Report on Extracting Forest Biomass Resources,* Mikamo Forest Owners' Association and Sumitomo Osaka Cement Company, Tochigi (in Japanese).

Möller, B. and Nielsen, P. S. (2007) Analyzing transport costs of Danish forest wood chip resources by means of continuous cost surfaces, Biomass Bioenerg. 31: 291-298.

Murakami, A., Ito, K., Saito, M., Aruga, K. and Tasaka, T. (2011) Extraction of production forests for sustainable forest management based on economic balances in the Kanuma area of Tochigi Prefecture, J. Forest Plann. 10: 245-254.

Nakahata, C., Aruga, K., Takei, Y., Yamaguchi, R., Ito, K., Murakami, A., Saito, M., Tasaka, T. and Kanetsuki, K. (2011) Improvement on operational efficiencies and costs of extracting thinned woods using a processor and a forwarder in Nasunogahara area (II)-based on comparative analyses of conventional operations and mechanized operations-, Bull. Utsunomiya Univ. Forest 47: 27-34 (in Japanese with English Summary).

Okawabata, O. (2003) An estimation of necessary manpower and cost of reforestation on cedar and cypress, J. Jpn. Forest Eng. Soc. 18: 195-200 (in Japanese).

Ranta, T. (2005) Logging residues from regeneration fellings for biofuel production-a GIS-based availability analysis in Finland, Biomass Bioenerg. 28: 171-182.

Sawaguchi, I. (1996) Studies on forest-road evaluation and forest-road standards in mountain forests: (I) Characteristics of parameters for forest-road evaluation, Bull. FFPRI 372: 1-110 (in Japanese with English summary). 
Shimotsuke newspaper (2009) A New Sawmill was Constructed in Kanuma city-Chips are Produced for the Fuel of Power Generation,* February 14, 2011 (in Japanese).

Tochigi Prefectural Government (2009) Forest and Forestry Statistics of Fiscal Year 2009 in Tochigi Prefecture. Tochigi Prefectural Government, Tochigi (in Japanese).

Tochigi Prefectural Government (2010a) Tochigi No Genkina Moridukuri Prefectural Tax (to Make Healthy Forests with Subsidies for Thinning Operations*) Business Evaluation Report of Fiscal Year 2009, Tochigi Prefectural Government, Utsunomiya (in Japanese).

Tochigi Prefectural Government (2010b) Forestation program standard unit cost table of Fiscal year 2010, Tochigi Prefectural Government, Tochigi, 2010 (in Japanese).

Tochigi Prefectural Gevernment (2010c) Watarasegawa regional forest plan, <http://www.pref.tochigi.lg.jp/d08/eco/shinrin/zenpan/ 1186548844240.html> (Accessed 27 Fuburary 2012)

Tochigi Prefectural Gevernment (2011) Nakagawa regional forest plan, $<$ http://www.pref.tochigi.lg.jp/d08/eco/shinrin/hozen /shinrinkeikaku.html> (Accessed 27 Fuburary 2012)

Yagi, K. and Nakata, T. (2007) Economic analysis on small-scale forest biomass gasification considering regional resource distribution and technical characteristics, J. Jpn. Inst. Energ. 86: 109-118 (in Japanese with English abstract).

Yamaguchi, R., Aruga, K., Murakami, A., Saito, M. and Ito, K. (2010) Development of the model to estimate the harvesting volumes and costs of logging residues considering economic balances of timber and logging residue harvesting in Sano city, Tochigi Prefecture, $J$. Jpn. Inst. Energ. 89: 982-995 (in Japanese with English Summary).

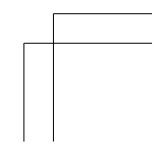


Yamamoto, H., Nakata, T. and Yabe, K. (2010) Design of biomass cofiring system considering resource distribution and transportation optimization, J. Jpn. Inst. Energ. 89: 42-52 (in Japanese with English Summary).

Yoshioka, T. and Sakai, H. (2005) Amount and availability of forest biomass as an energy resource in a mountain region in Japan: A GIS-based analysis, Croat. J. Forest Eng. 26: 59-70.

Zenkoku Ringyo Kairyo Fukyu Kyokai (2001) Management of Forestry Mechanization, Zenkoku Ringyo Kairyo Fukyu Kyokai, Tokyo (in Japanese).

* Translated by the authors. 